\title{
GAS EXCHANGE AND PRODUCTION OF PASSION FRUIT AS AFFECTED BY CATIONIC NATURE OF IRRIGATION WATER ${ }^{1}$
}

\author{
FRANCISCO JEAN DA SILVA PAIVA ${ }^{2 *}$, GEOVANI SOARES DE LIMA ${ }^{2}$, VERA LÚCIA ANTUNES DE LIMA², \\ KHEILA GOMES NUNES ${ }^{2}$, PEDRO DANTAS FERNANDES ${ }^{2}$
}

\begin{abstract}
Yellow passion fruit is a fruit species widely cultivated throughout the Brazilian semi-arid territory, but its yield is affected by the quality of the waters of this region. In this context, the objective was to evaluate the gas exchange and production of passion fruit cv. BRS Rubi do Cerrado irrigated with waters of different cationic natures. The study was conducted in drainage lysimeters under greenhouse conditions in Campina Grande, PB, Brazil, in a randomized block design, and the treatments were eight cationic natures of irrigation water $\left(\mathrm{S}_{1}-\mathrm{C}\right.$ Control; $\mathrm{S}_{2}-\mathrm{Na}^{+} ; \mathrm{S}_{3}-\mathrm{Ca}^{2+} ; \mathrm{S}_{4}-\mathrm{Mg}^{2+} ; \mathrm{S}_{5}-\mathrm{Na}^{+}+\mathrm{Ca}^{2+} ; \mathrm{S}_{6}-\mathrm{Na}^{+}+\mathrm{Mg}^{2+} ; \mathrm{S}_{7}-\mathrm{Ca}^{2+}+\mathrm{Mg}^{2+}$ and $\mathrm{S}_{8}-\mathrm{Na}^{+}+\mathrm{Ca}^{2+}+\mathrm{Mg}^{2+}$ ) with three replicates. Plants in the control treatment were irrigated with water of low electrical conductivity $\left(\mathrm{ECW}=0.4 \mathrm{dS} \mathrm{m}^{-1}\right)$, while those of the other treatments were irrigated using water with ECw of $3.5 \mathrm{dS} \mathrm{m}$. The treatments $\mathrm{Na}^{+}+\mathrm{Ca}^{2+}, \mathrm{Na}^{+}+\mathrm{Mg}^{2+}$ and $\mathrm{Ca}^{2+}+\mathrm{Mg}^{2+}$ were prepared in the equivalent ratio of $1: 1$, and $\mathrm{Na}^{+}+\mathrm{Ca}^{2+}+\mathrm{Mg}^{2+}$ in the ratio $7: 2: 1$, respectively. Water salinity of $3.5 \mathrm{dS} \mathrm{m}$ reduced gas exchange, and stomatal conductance and transpiration were the most sensitive variables of passion fruit. The number of fruits of passion fruit cv. BRS Rubi do Cerrado decreased with water salinity, regardless of the cationic nature. The waters of calcic and calcic+magnesian nature caused the greatest deleterious effects on the production variables of passion fruit, at 259 days after transplanting.
\end{abstract}

Keywords: Passiflora edulis L. Fruit growing. Irrigation. Salinity.

\section{TROCAS GASOSAS E PRODUC̃̃̃ DO MARACUJAZEIRO EM FUNÇ̃̃O DA NATUREZA CATIÔNICA DA ÁGUA DE IRRIGAÇÃO}

RESUMO - O maracujazeiro amarelo é uma espécie frutífera bastante cultivada em todo o território Semiárido brasileiro, contudo, seu rendimento produtivo é afetado pela qualidade das águas desta região. Neste contexto, objetivou-se avaliar as trocas gasosas e a produção do maracujazeiro cv. BRS Rubi do Cerrado irrigado com águas de distintas naturezas catiônicas. O estudo foi conduzido em lisímetros de drenagem em condições de casa de vegetação em Campina Grande, $\mathrm{PB}$, no delineamento em blocos casualizados, sendo os tratamentos oito naturezas catiônicas da água de irrigação $\left(\mathrm{S}_{1}-\mathrm{T}\right.$ estemunha; $\mathrm{S}_{2}-\mathrm{Na}^{+} ; \mathrm{S}_{3}-\mathrm{Ca}^{2+} ; \mathrm{S}_{4}-\mathrm{Mg}^{2+} ; \mathrm{S}_{5}-\mathrm{Na}^{+}+\mathrm{Ca}^{2+}$; $\mathrm{S}_{6}-\mathrm{Na}^{+}+\mathrm{Mg}^{2+} ; \mathrm{S}_{7}-\mathrm{Ca}^{2+}+\mathrm{Mg}^{2+} \mathrm{e} \mathrm{S}_{8}-\mathrm{Na}^{+}+\mathrm{Ca}^{2+}+\mathrm{Mg}^{2+}$ ) com três repetições. As plantas do tratamento testemunha foram irrigadas com água de baixa condutividade elétrica $\left(\mathrm{CEa}=0,4 \mathrm{dS} \mathrm{m}^{-1}\right)$, já os demais tratamentos foram irrigadas com CEa de $3,5 \mathrm{dS} \mathrm{m}{ }^{-1}$. Os tratamentos $\mathrm{Na}^{+}+\mathrm{Ca}^{2+} ; \mathrm{Na}^{+}+\mathrm{Mg}^{2+} \mathrm{e} \mathrm{Ca}^{2+}+\mathrm{Mg}^{2+}$ foram preparados na proporção equivalente de $1: 1$ e $\mathrm{Na}^{+}+\mathrm{Ca}^{2+}+\mathrm{Mg}^{2+}$ na proporção $7: 2: 1$, respectivamente. A salinidade da água de $3,5 \mathrm{dS} \mathrm{m}^{-1}$ reduziu as trocas gasosas, sendo a condutância estomática e a transpiração as variáveis mais sensíveis do maracujazeiro. O número de frutos do maracujazeiro cv. BRS Rubi do Cerrado diminuiu com a salinidade da água, independente da natureza catiônica. As águas de natureza cálcica e o cálcica+magnesiana promoveram os maiores efeitos deletérios sob as variáveis de produção do maracujazeiro, aos 259 dias após o transplantio.

Palavras-chave: Passiflora edulis Sims. Fruticultura. Irrigação. Salinidade.

\footnotetext{
*Corresponding author

${ }^{1}$ Received for publication in $06 / 17 / 2020$; accepted in $06 / 01 / 2021$.

Paper extracted from the dissertation of the first author

${ }^{2}$ Academic Unit of Agricultural Engineering, Universidade Federal de Campina Grande, Campina Grande, PB, Brazil; je.an_93@hotmail.com - ORCID: 0000-0001-7603-4782, geovanisoareslima@gmail.com - ORCID: 0000-0001-9960-1858, antuneslima@gmail.com - ORCID: 0000-0001-7495-6935, kheilagomesnunes@gmail.com - ORCID: 0000-0003-1520-843X, pedrodantasfernandes@gmail.com-ORCID: 0000-0001-5070-1030.
} 


\section{INTRODUCTION}

Brazil is the world's largest producer and consumer of passion fruit, having produced in 2018 more than 602,000 tons in a planted area of 43,248 hectares (IBGE, 2019). The highlight in passion fruit production is related to its physical-chemical characteristics, high yield and juice acceptance by the consumer market, the main factors responsible for boosting the commercialization of fruits, significantly influencing the expansion and emergence of new cultivated areas (SANTOS et al., 2014).

In the semi-arid region of Brazil, due to adverse climatic conditions, characterized by having in most of the year high temperatures, high evapotranspiration rates and low rainfall, distributed irregularly in space and time, the use of irrigation becomes indispensable for the agricultural exploitation. However, due to the high demand for good quality water, together with the need to produce food, the use of lower quality water in agricultural activities has become frequent (LIRA et al., 2015; MUNNS; GILLIHAM, 2015; RODRIGUES et al., 2018).

In this scenario, the available water resources are characterized mainly by containing high concentrations of salts, but they vary according to the local geology and the type of source, generally with predominance of chlorinated waters, especially of sodium, calcium and magnesium, and, in some cases, potassium (MEDEIROS; LISBOA; OLIVEIRA, 2003; NASCIMENTO et al., 2017; LIMA et al., 2019).

For certain crops, the excess of salts diluted in irrigation water is considered as a limiting factor to agricultural production, for drastically affecting the growth, yield and quality of agricultural products. When subjected to salt stress, the ions present in the soil solution limit the capacity to absorb water and nutrients by the roots, causing physiological disorders to plants (NOBRE et al., 2013). Given this condition, plants tend to close their stomata, consequently causing disturbances in water relations, in addition to the accumulation of potentially toxic ions in plant metabolism (AMORIM et al., 2010).

In this context, several studies have been conducted with the objective of evaluating the deleterious effects of salinity on several aspects in passion fruit crop (WANDERLEY et al., 2018; FREIRE; NASCIMENTO, 2018; SOUZA et al., 2018; LIMA et al., 2020a). However, these studies were limited to evaluating the different salinity levels, so it is necessary to conduct studies related to the effects of the different cationic compositions of irrigation water on the cultivation of passion fruit cv. BRS Rubi do Cerrado, as a way to identify the cation which promotes the highest and/or lowest sensitivity in the crop under the conditions of the Brazilian semi -arid region, constituting an important tool to assist in the management of species cultivated under conditions of high concentrations of salts in water, especially of distinct cationic nature.

In view of the above, the objective of this study was to evaluate the gas exchange and production of passion fruit cv. BRS Rubi do Cerrado irrigated with waters of different cationic natures.

\section{MATERIAL AND METHODS}

The experiment was carried out from March 2019 to January 2020 in a protected environment of the Academic Unit of Agricultural Engineering of the Federal University of Campina Grande (UFCG), Campus of Campina Grande, PB, Brazil, located by the local geographic coordinates $07^{\circ} 15^{\prime} 18^{\prime \prime} \mathrm{S}$, and $35^{\circ} 52^{\prime} 28^{\prime \prime} \mathrm{W}$ and altitude of $550 \mathrm{~m}$.

The seedlings were grown in polyethylene bags with volumetric capacity of $1,472 \mathrm{~mL}$, filled with substrate composed of the mixture of soil, washed sand, and earthworm humus, in the proportion of 84,15 and $1 \%$, respectively. Before and after sowing, irrigations were performed daily with low-salinity water $\left(\mathrm{ECw}=0.4 \mathrm{dS} \mathrm{m}^{-1}\right)$ in order to keep the substrate close to the level of field capacity.

Transplanting was performed when the seedlings reached $50 \mathrm{~cm}$ in height and started the production of tendrils (45 days after sowing - DAS). After transplantation, all lysimeters were irrigated with low-salinity water $\left(0.4 \mathrm{dS} \mathrm{m}^{-1}\right)$, in order to keep the soil with moisture content at the level corresponding to field capacity. The plants were trained in a vertical trellis system, constructed using smooth galvanized steel wire no. 12 , at $1.7 \mathrm{~m}$ high from the surface of the soil inside the lysimeter. The treatments began to be applied when the main stem of the plants reached the trellis height.

Nylon string was used to fix the plants and, when the main branch exceeded $10 \mathrm{~cm}$ from the trellis height, the first pruning was performed, aiming to induce the secondary branches. When the secondary branches reached one meter in length, the second pruning was performed to establish the growth of the tertiary branches and form the 'curtain' and, when they reached a distance of $20 \mathrm{~cm}$ from the ground, the third pruning was performed to avoid their contact with the soil. Throughout the experiment, scissors were used to eliminate unwanted branches as well as tendrils that appeared along the plants.

The treatments consisted of seven combinations of irrigation water of different cationic natures, in addition to the control treatment (publicsupply water); with this, the treatments corresponded to: $\mathrm{S}_{1}-\mathrm{Control} ; \mathrm{S}_{2}-\mathrm{Na}^{+} ; \mathrm{S}_{3}-\mathrm{Ca}^{2+} ; \mathrm{S} 4-\mathrm{Mg}^{2+} ; \mathrm{S}_{5}-$ $\mathrm{Na}^{+}+\mathrm{Ca}^{2+} ; \mathrm{S}_{6}-\mathrm{Na}^{+}+\mathrm{Mg}^{2+} ; \mathrm{S}_{7}-\mathrm{Ca}^{2+}+\mathrm{Mg}^{2+}$ and $\mathrm{S}_{8}$ $-\mathrm{Na}^{+}+\mathrm{Ca}^{2+}+\mathrm{Mg}^{2+}$. Plants in the control treatment $\left(\mathrm{S}_{1}\right)$ were irrigated with public-supply water, with 
electrical conductivity $(\mathrm{ECw})$ of $0.4 \mathrm{dS} \mathrm{m}^{-1}$, while the other treatments $\left(\mathrm{S}_{2} ; \mathrm{S}_{3} ; \mathrm{S}_{4} ; \mathrm{S}_{5} ; \mathrm{S}_{6} ; \mathrm{S}_{7}\right.$ and $\left.\mathrm{S}_{8}\right)$ received $\mathrm{ECW}$ of $3.5 \mathrm{dS} \mathrm{m}{ }^{-1}$. The treatments $\mathrm{Na}^{+}+$ $\mathrm{Ca}^{2+}, \mathrm{Na}^{+}+\mathrm{Mg}^{2+}$ and $\mathrm{Ca}^{2+}+\mathrm{Mg}^{2+}$ were prepared in such a way to have an equivalent ratio of $1: 1$, and the treatment $\mathrm{Na}^{+}+\mathrm{Ca}^{2+}+\mathrm{Mg}^{2+}$, a ratio of $7: 2: 1$, respectively.

A randomized block design was used, consisting of eight treatments and three replicates, totaling 24 experimental plots. The plants were grown in drainage lysimeters at spacing of $1.5 \mathrm{~m}$ between rows and $2 \mathrm{~m}$ between plants. At the bottom of the lysimeters, two holes were drilled and drains with dimensions of $18 \mathrm{~mm}$ diameter and $20 \mathrm{~cm}$ length were connected. Then, a geotextile (Bidim OP 30 type) was placed to avoid clogging of the drains, followed by a layer of crushed stone to facilitate drainage. To collect the drained volume referring to the leaching fraction, a plastic bottle with capacity of $2 \mathrm{~L}$ was placed below each drain, and the drainage value was accounted for and used for soil water balance.

The lysimeters had dimensions of $68 \times 60 \mathrm{~cm}$ (height and diameter, respectively), with a volumetric capacity of $0.2 \mathrm{~m}^{3}$, and were filled with $240 \mathrm{~kg}$ of soil, with a free height of $10 \mathrm{~cm}$ at the top of the lysimeter in order to facilitate irrigations. Prior to transplanting, $22 \mathrm{~L}$ of water were applied to raise soil moisture to the level corresponding to field capacity, using the soil water balance method. The soil used was classified as sandy clay loam, dystrophic (EMBRAPA, 2018), collected at a depth of $0-30 \mathrm{~cm}$ (horizon $\mathrm{A}$ ), in an area with native vegetation, coming from the municipality of Alagoa Nova, PB, with physical-hydraulic and chemical attributes obtained according to the methodology proposed by Teixeira et al. (2017): $\mathrm{Ca}^{2+}, \mathrm{Mg}^{2+}, \mathrm{Na}^{+}$, $\mathrm{K}^{+}, \mathrm{Al}^{3+}+\mathrm{H}^{+}=1.67,1.56,0.04,79.30$ and 7.21 $\mathrm{cmol}_{\mathrm{c}} \mathrm{kg}^{-1}$, respectively; $\mathrm{pH}$ (water $1: 2.5$ ) $=5.3$; $\mathrm{ECse}=0.41 \mathrm{dS} \mathrm{m}^{-1}$; organic matter $=2.863 \mathrm{dag} \mathrm{kg}^{-1}$; sand, silt and clay $=68.8,9.6$ and $21.6 \mathrm{dag} \mathrm{kg}^{-1}$, respectively; soil bulk density $\left(\mathrm{kg} \mathrm{dm}^{-3}\right)=1.16$.

Irrigation waters were obtained from the dissolution of sodium $(\mathrm{NaCl})$, calcium $\left(\mathrm{CaCl}_{2} \cdot 2 \mathrm{H}_{2} \mathrm{O}\right)$, and magnesium $\left(\mathrm{MgCl}_{2} \cdot 6 \mathrm{H}_{2} \mathrm{O}\right)$ chlorides according to the pre-established treatments, based on the electrical conductivity of water acquired from the supply network of the city of Campina Grande, PB, as described in the equation of Richards (1954), considering the relationship between the ECW (electrical conductivity of the public-supply water) and the concentration of salts

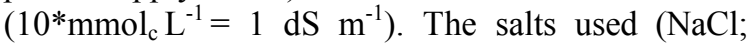
$\left.\mathrm{CaCl}_{2} \cdot 2 \mathrm{H}_{2} \mathrm{O} ; \mathrm{MgCl}_{2} \cdot 6 \mathrm{H}_{2} \mathrm{O}\right)$ had purity of $99.9,74$ and $100 \%$, respectively. After preparation and calibration of $\mathrm{ECw}$, the water was stored in plastic containers with capacity of $100 \mathrm{~L}$, properly identified with the respective treatments and closed, in order to avoid evaporation.

The irrigations were carried out daily, applying the volume of water necessary to maintain soil moisture close to the maximum water retention capacity. In each irrigation, the volume of water determined to meet the water needs of the plants was applied, through water balance in the root zone, obtained by the difference between the volume applied and the volume drained, calculated every week. In order to avoid the accumulation of salts in the root zone, a leaching fraction of 0.15 (AYERS; WESTCOT, 1999) was applied. The volume drained was quantified and the electrical conductivity of the drained water was measured; these parameters were used in the calculations to determine the leaching fraction.

When the holes were opened, planting fertilization was carried out according to São José et al. (2000), applying $250 \mathrm{~g}$ of single superphosphate and $100 \mathrm{~g}$ of potassium chloride at $60 \%$, in addition to $150 \mathrm{~g}$ of single superphosphate per plant at the beginning of flowering. Nitrogen and potassium fertilizations were performed monthly, using ammonium sulfate as nitrogen source and potassium chloride as potassium source. In the crop formation stage, the $1 \mathrm{~N}: 1 \mathrm{~K}$ ratio was used taking as reference $10 \mathrm{~g}$ of nitrogen; from the beginning of flowering, the $\mathrm{N}$ dose was raised to 20 and the $\mathrm{K}$ dose to $30 \mathrm{~g}$, increasing the $\mathrm{N}: \mathrm{K}$ ratio to $1: 1.5$. Foliar fertilization was also performed monthly, with micronutrients.

When the flowering stage began, due to the low number of carpenter bees (Xylocopa spp), the main natural pollinating agent of passion fruit, since the experiment was carried out in a protected environment, artificial pollination was carried out daily from $13: 00$ to $17: 00$ hours manually, by touching the fingertips on the anthers until they were covered with pollen and then lightly touching the stigmas of another flower on another plant. Manual pollination began in the second week of September 2019 extending to the second week of November of that year, so the flowering period was eight weeks.

Phytosanitary control was performed when necessary, using agrochemicals, according to recommendations for the crop and following the doses recommended by the manufacturers of each product. Weed control was performed by manual weeding, between the rows of the drainage lysimeters and around the plant collar. In addition, scarifications were also performed using a manual scarifier to eliminate invasive plants around the plant collar and decompress the surface layer of the soil.

The effects of the different treatments on passion fruit crop were measured at 180 days after transplanting (DAT), by evaluating the $\mathrm{CO}_{2}$ assimilation rate $(A)\left(\mu \mathrm{mol} \mathrm{m} \mathrm{m}^{-2} \mathrm{~s}^{-1}\right)$, transpiration $(E)$ (mol of $\mathrm{H}_{2} \mathrm{O} \mathrm{m}^{-1} \mathrm{~s}^{-1}$ ), internal $\mathrm{CO}_{2}$ concentration $(\mathrm{Ci})$ $\left(\mu \mathrm{mol} \mathrm{m} \mathrm{m}^{-2} \mathrm{~s}^{-1}\right)$ and stomatal conductance $(\mathrm{gs})$ ( $\mathrm{mol}$ of $\mathrm{H}_{2} \mathrm{O} \mathrm{m} \mathrm{m}^{-1} \mathrm{~s}^{-1}$ ), determined in the third leaf counted from the apex, using the portable photosynthesis meter (IRGA) called "LCPro+", from ADC BioScientific Ltda. 
Fruit harvesting started at 180 DAT. Fruits that detached from the mother plant and fell to the ground were considered in full maturation stage. Still in the almost ripe stage, the fruits of each plant were identified using a marker for whiteboard with the respective numbers of the pots.

Passion fruit production was evaluated by determining the number of fruits per plant (NFruP), performed by direct counting of fruits that reached the full maturation stage, average fruit mass (AFM), and fresh fruit mass (FFM), using a benchtop scale, polar diameter (PD) and equatorial diameter (ED), using a digital caliper and measured as the fruits were harvested, with results expressed in millimeters (mm).

The data obtained were evaluated by analysis of variance by the F test; when significant, the means comparison test (Scott-Knott $\mathrm{p}<0.05)$ and the contrasts between the means of the treatments were performed using the statistical program SISVARESAL. The contrasts were defined as follows: $\hat{y}_{1}\left(\mathrm{~S}_{1}\right.$ vs $\left.\mathrm{S}_{2} ; \mathrm{S}_{3} ; \mathrm{S}_{4} ; \mathrm{S}_{5} ; \mathrm{S}_{6} ; \mathrm{S}_{7} ; \mathrm{S}_{8}\right) ; \hat{\mathrm{y}}_{2}\left(\mathrm{~S}_{2}\right.$ vs $\left.\mathrm{S}_{3}\right) ; \hat{\mathrm{y}}_{3}\left(\mathrm{~S}_{2}\right.$ vs $\left.\mathrm{S}_{4}\right)$; $\hat{\mathrm{y}}_{4}\left(\mathrm{~S}_{3} \mathrm{vs}_{5}\right) ; \hat{\mathrm{y}}_{5}\left(\mathrm{~S}_{5} \mathrm{vs} \mathrm{S}_{6} ; \mathrm{S}_{7} ; \mathrm{S}_{8}\right) ; \hat{\mathrm{y}}_{6}\left(\mathrm{~S}_{4} \mathrm{vs} \mathrm{S}_{5}\right)$ and $\hat{\mathrm{y}}_{7}$ $\left(\mathrm{S}_{2}\right.$ vs $\left.\mathrm{S}_{7}\right)$.

\section{RESULTS AND DISCUSSION}

The summary of the analysis of variance (Table 1) showed that there was a significant effect $(\mathrm{p}<0.01)$ of the different cationic natures of irrigation water on the $\mathrm{CO}_{2}$ assimilation rate $(A)$, stomatal conductance $(g S)$ and transpiration $(E)$ of yellow passion fruit plants cv. BRS Rubi do Cerrado, at 180 days after transplanting.

Table 1. Summary of the analysis of variance for $\mathrm{CO}_{2}$ assimilation rate $(A)$, internal $\mathrm{CO}_{2}$ concentration $(\mathrm{C} i)$, stomatal conductance $(g s)$ and transpiration $(E)$ of yellow passion fruit plants cv. BRS Rubi do Cerrado irrigated with water of different cationic natures, at 180 days after transplanting.

\begin{tabular}{cccccc}
\hline \multirow{2}{*}{ VS/Contrasts $^{\#}$} & DF & \multicolumn{4}{c}{ Mean square } \\
\cline { 3 - 6 } & & $A$ & $C i$ & $g s$ & $E$ \\
\hline Blocks & 2 & $2.7274^{* *}$ & $2319.50^{\text {ns }}$ & $0.0006^{\text {ns }}$ & $0.5780^{*}$ \\
CNW & $(7)$ & $8.0025^{* *}$ & $1089.66^{\text {ns }}$ & $0.0033^{* *}$ & $2.0951^{* *}$ \\
$\hat{y}_{1}$ & 1 & $19.0688^{* *}$ & $135.72^{\text {ns }}$ & $0.0212^{* *}$ & $11.8243^{* *}$ \\
$\hat{y}_{2}$ & 1 & $4.9868^{* *}$ & $1204.16^{\text {ns }}$ & $0.0008^{\text {ns }}$ & $1.2512^{* *}$ \\
$\hat{y}_{3}$ & 1 & $18.9748^{* *}$ & $1120.66^{\text {ns }}$ & $0.0010^{*}$ & $1.3632^{* *}$ \\
$\hat{y}_{4}$ & 1 & $2.9821^{*}$ & $1040.16^{\text {ns }}$ & $0.0004^{\text {ns }}$ & $0.6016^{*}$ \\
$\hat{y}_{5}$ & 1 & $11.3793^{* *}$ & $684.69^{\text {ns }}$ & $0.0000^{\text {ns }}$ & $0.0014^{\text {ns }}$ \\
$\hat{y}_{6}$ & 1 & $14.8208^{* *}$ & $1290.66^{\text {ns }}$ & $0.0006^{\text {ns }}$ & $0.6800^{*}$ \\
$\hat{y}_{7}$ & 1 & $4.1833^{* *}$ & $20.16^{\text {ns }}$ & $0.0000^{\text {ns }}$ & $0.0008^{\text {ns }}$ \\
Residual & 14 & 0.4324 & 800.92 & 0.0002 & 0.0960 \\
CV $(\%)$ & & 13.01 & 13.31 & 24.16 & 13.72 \\
\hline
\end{tabular}

${ }^{\#} \hat{\mathrm{y}}_{1}\left(\mathrm{~S}_{1} \mathrm{vs} \mathrm{S}_{2} ; \mathrm{S}_{3} ; \mathrm{S}_{4} ; \mathrm{S}_{5} ; \mathrm{S}_{6} ; \mathrm{S}_{7} ; \mathrm{S}_{8}\right) ; \hat{\mathrm{y}}_{2}\left(\mathrm{~S}_{2} \mathrm{vs} \mathrm{S}_{3}\right) ; \hat{\mathrm{y}}_{3}\left(\mathrm{~S}_{2} \mathrm{vs} \mathrm{S}_{4}\right) ; \hat{\mathrm{y}}_{4}\left(\mathrm{~S}_{3} \mathrm{vs} \mathrm{S}_{5}\right) ; \hat{\mathrm{y}}_{5}\left(\mathrm{~S}_{5} \mathrm{vs} \mathrm{S}_{6} ; \mathrm{S}_{7} ; \mathrm{S}_{8}\right) ; \hat{\mathrm{y}}_{6}\left(\mathrm{~S}_{4} \mathrm{vs} \mathrm{S}_{5}\right)$ and $\hat{\mathrm{y}}_{7}\left(\mathrm{~S}_{2} \mathrm{vs}\right.$ $\mathrm{S}_{7}$ ); SV - Source of variation; DF - Degree of freedom; CV - Coefficient of variation; CNW - Cationic Nature of Water; ( ) Significant at 0.05 probability level; $\left({ }^{* *}\right)$ Significant at 0.01 probability level; $\left({ }^{\mathrm{ns}}\right)$ not significant.

It is verified, through the means comparison test for the $\mathrm{CO}_{2}$ assimilation rate $(A)$ (Figure 1A), that plants cultivated with low-salinity water $\left(\mathrm{S}_{1}\right)$ and those irrigated with water of sodic $\left(\mathrm{S}_{2}\right)$ and sodic + calcic $\left(\mathrm{S}_{5}\right)$ composition obtained the highest values, equal to $7.41,6.68$ and $6.27 \mu \mathrm{mol} \mathrm{CO}_{2} \mathrm{~m}^{-2} \mathrm{~s}^{-1}$, compared to plants grown with water salinized by $\mathrm{Ca}^{2+}\left(\mathrm{S}_{3}\right), \mathrm{Mg}^{2+}\left(\mathrm{S}_{4}\right), \mathrm{Na}^{+}+\mathrm{Mg}^{2+}\left(\mathrm{S}_{6}\right), \mathrm{Ca}^{2+}+\mathrm{Mg}^{2+}$ $\left(\mathrm{S}_{7}\right)$ and $\mathrm{Na}^{+}+\mathrm{Ca}^{2+}+\mathrm{Mg}^{2+}\left(\mathrm{S}_{8}\right)$. However, there was no significant effect when comparing the plants of the treatment $S_{1}$ with plants irrigated with the treatments $\mathrm{S}_{2}$ and $\mathrm{S}_{5}$. Among the different cationic compositions, it is observed that plants cultivated with water salinized by magnesium $\left(\mathrm{S}_{4}\right)$ and sodium + calcium + magnesium $\left(\mathrm{S}_{8}\right)$ obtained the lowest values of $\mathrm{CO}_{2}$ assimilation rate, which corresponded to 3.13 and $3.00 \mu \mathrm{mol} \mathrm{CO}_{2} \mathrm{~m}^{-2} \mathrm{~s}^{-1}$, respectively, at 180 DAT.
The reduction in $\mathrm{CO}_{2}$ assimilation rate observed in this study may be related to the effect of salts on the soil, due to the reduction in the osmotic potential of the solution, inhibiting the absorption of water and nutrients by plants, resulting in stomatal closure. The increase in the $\mathrm{CO}_{2}$ assimilation rate is related to the higher $\mathrm{CO}_{2}$ concentration observed inside the leaves, which may result from stomatal closure in response to abiotic stresses (JADOSKI; SKAR; SALVADOR, 2005), in this case, the water stress caused by excess of salts in the soil. Reduction in $\mathrm{CO}_{2}$ assimilation rate in passion fruit plants as a function of increasing salinity of irrigation water have also been observed by Andrade et al. (2019) and by Silva et al. (2019) in studies conducted under greenhouse conditions. 

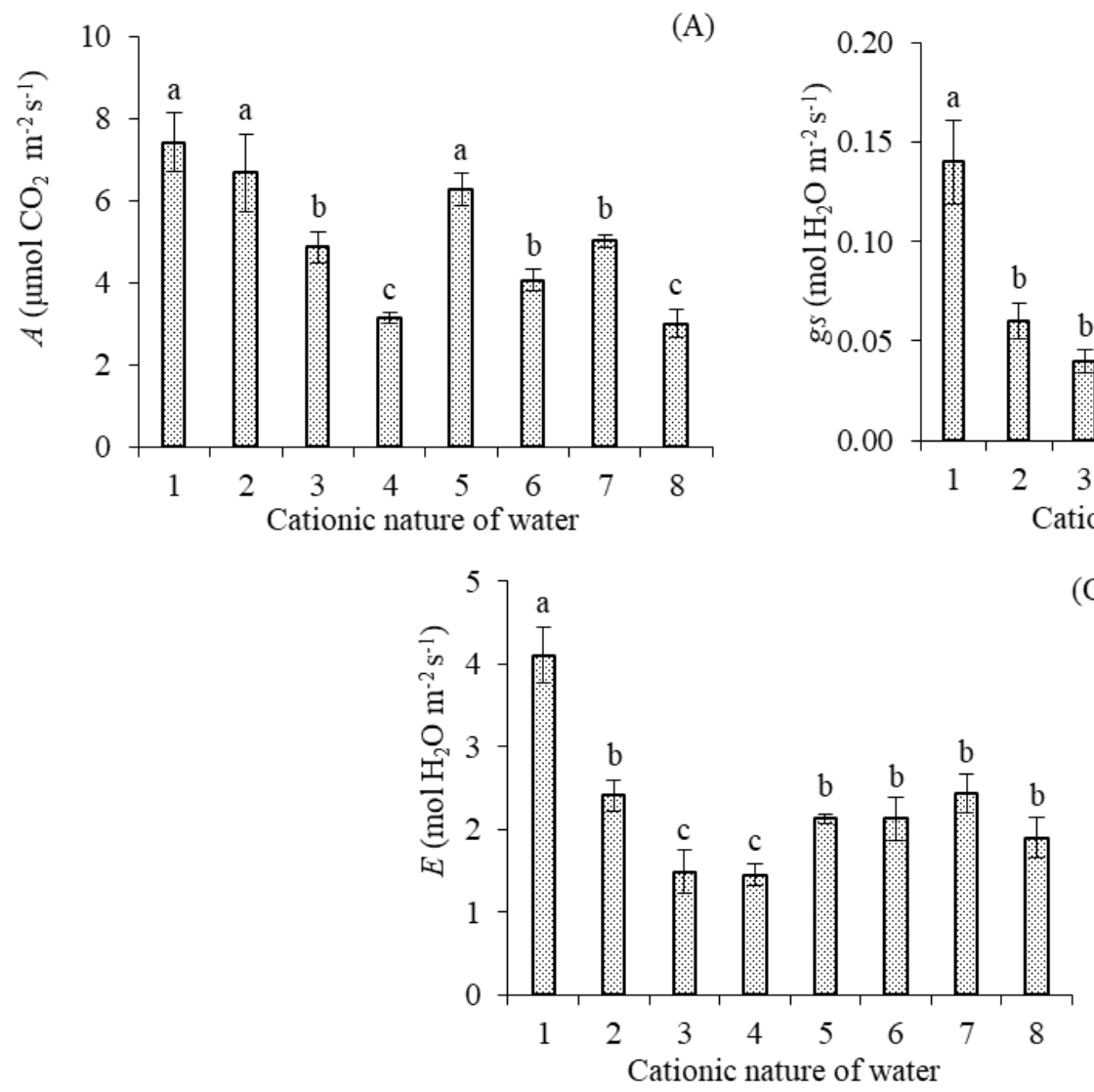

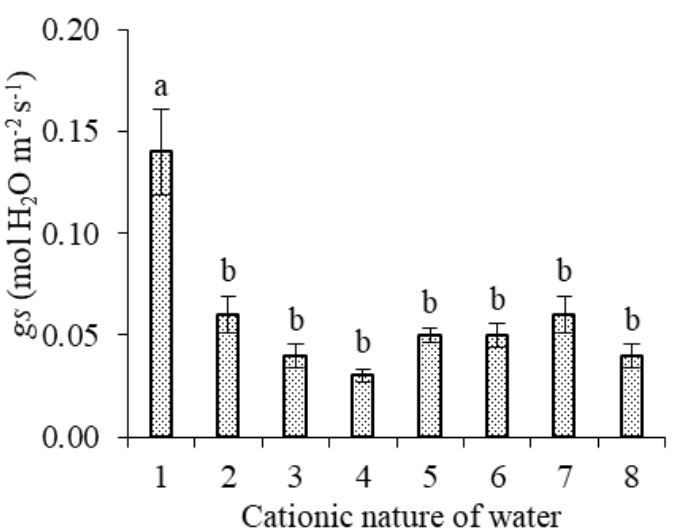

(C)

1 - Control; $2-\mathrm{Na}^{+} ; 3-\mathrm{Ca}^{2+} ; 4-\mathrm{Mg}^{2+} ; 5-\mathrm{Na}^{+}+\mathrm{Ca}^{2+} ; 6-\mathrm{Na}^{+}+\mathrm{Mg}^{2+} ; 7-\mathrm{Ca}^{2+}+\mathrm{Mg}^{2+}$ and $8-\mathrm{Na}^{+}+\mathrm{Ca}^{2+}+\mathrm{Mg}^{2+}$. Bars represent standard error of the mean $(n=3)$. Means followed by equal letters do not differ by the Scott-Knott test $(\mathrm{p} \leq 0.05)$.

Figure 1. $\mathrm{CO}_{2}$ assimilation rate - $A(\mathrm{~A})$, stomatal conductance - $g s(\mathrm{~B})$ and transpiration - $E(\mathrm{C})$ of yellow passion fruit plants cv. BRS Rubi do Cerrado as a function of the cationic nature of irrigation water, at 180 days after transplanting.

For stomatal conductance $(g s)$ (Figure 1B), it is verified that plants grown under the lowest salinity level $\left(S_{1}\right)$ differed statistically from all those that were subjected to the different cationic natures $\left(\mathrm{S}_{2}\right.$, $\mathrm{S}_{3}, \mathrm{~S}_{4}, \mathrm{~S}_{5}, \mathrm{~S}_{6}, \mathrm{~S}_{7}$ and $\left.\mathrm{S}_{8}\right)$. The means comparison test (Figure 1B) showed increments of $0.08,0.10,0.11$, $0.09,0.09,0.08$ and $0.10 \mathrm{~mol} \mathrm{H}_{2} \mathrm{O} \mathrm{m} \mathrm{m}^{-2} \mathrm{~s}^{-1}$, respectively, in the stomatal conductance of plants grown under ECw of $0.4 \mathrm{dS} \mathrm{m}^{-1}\left(\mathrm{~S}_{1}\right)$ compared to the different cationic natures of water $\left(\mathrm{S}_{2}, \mathrm{~S}_{3}, \mathrm{~S}_{4}, \mathrm{~S}_{5}, \mathrm{~S}_{6}\right.$, $\mathrm{S}_{7}$ and $\mathrm{S}_{8}$ ). It is also verified that there was no statistical difference between treatments $\mathrm{S}_{2}, \mathrm{~S}_{3}, \mathrm{~S}_{4}$, $\mathrm{S}_{5}, \mathrm{~S}_{6}, \mathrm{~S}_{7}$ and $\mathrm{S}_{8}$.

The stress caused by the high concentration of salts above the level tolerated by the crop leads to reduction in several physiological parameters of plants, such as water use efficiency, net $\mathrm{CO}_{2}$ assimilation rate, transpiration and stomatal conductance in glycophytes species, such as passion fruit crop (FREIRE et al., 2014; LI et al., 2017). Lima et al. (2020b), studying the physiological, anatomical and nutritional growth responses of two passion fruit species under saline conditions ( 0 and $150 \mathrm{mM} \mathrm{NaCl}$ ), observed a reduction in the stomatal conductance of plants of the species Passiflora edulis as a function of water salinity.

For transpiration (E) (Figure 1C), it was verified that plants irrigated with water with lower electrical conductivity $\left(\mathrm{S}_{1}\right)$ obtained the highest values (4.11 mol $\left.\mathrm{H}_{2} \mathrm{O} \mathrm{m}^{-2} \mathrm{~s}^{-1}\right)$, differing statistically from plants cultivated under the highest salinity $\left(\mathrm{S}_{2}\right.$; $\mathrm{S}_{3} ; \mathrm{S}_{4} ; \mathrm{S}_{5} ; \mathrm{S}_{6} ; \mathrm{S}_{7}$ and $\mathrm{S}_{8}$ ). The lowest values were obtained when the plants were irrigated with water salinized by calcium $\left(\mathrm{S}_{3}\right)$ and magnesium $\left(\mathrm{S}_{4}\right)$. There was no significant difference between the plants that received the treatments $\mathrm{S}_{2}, \mathrm{~S}_{5}, \mathrm{~S}_{6}, \mathrm{~S}_{7}$ and $\mathrm{S}_{8}$.

The decrease in the leaf transpiration of plants may be related to the effect of salts on soil and plant, as the increase in irrigation water salinity allowed the accumulation of salts in the soil profile, close to the root system, causing the osmotic effect, hindering the absorption of water and nutrients by the roots, and in response to this stress the plant established greater control over the stomatal opening in order to avoid excessive water loss by transpiration (SOUZA et al., 2011). Reduction in transpiration and stomatal conductance as a function of salinity of irrigation water were also observed in passion fruit plants by Andrade et al. (2019). 
According to the summary of the analysis of variance for the contrasts of means for the $\mathrm{CO}_{2}$ assimilation rate $(A)$ (Table 2), there was a significant effect when the plants irrigated with $\mathrm{ECW}$ of $0.4 \mathrm{dS} \mathrm{m} \mathrm{m}^{-1}\left(\mathrm{~S}_{1}\right)$ were compared with those cultivated with ECw of $3.5 \mathrm{dS} \mathrm{m}{ }^{-1}\left(\mathrm{~S}_{2} ; \mathrm{S}_{3} ; \mathrm{S}_{4} ; \mathrm{S}_{5} ; \mathrm{S}_{6}\right.$ $\mathrm{S}_{7}$ and $\mathrm{S}_{8}$ ), with an increase of $2.69 \mathrm{~mol} \mathrm{CO}_{2} \mathrm{~m}^{-2} \mathrm{~s}^{-1}$ in plants subjected to $\mathrm{ECW}=0.4 \mathrm{dS} \mathrm{m}^{-1}$ compared to those under the highest salinity level $\left(3.5 \mathrm{dS} \mathrm{m}^{-1}\right)$.

Table 2. Estimate of mean referring to the $\mathrm{CO}_{2}$ assimilation rate $(A)$, internal $\mathrm{CO}_{2}$ concentration $(\mathrm{Ci})$, stomatal conductance $(g s)$ and transpiration $(E)$ of yellow passion fruit plants cv. BRS Rubi do Cerrado irrigated with water of different cationic natures, at 180 days after transplanting.

\begin{tabular}{ccccc}
\hline \multirow{2}{*}{ Contrasts $^{\#}$} & \multicolumn{5}{c}{ Mean estimate } & gs \\
\cline { 2 - 5 } & $A$ & $C i$ & 0.09 & 2.12 \\
\hline$\hat{y}_{1}$ & 2.69 & - & - & 0.91 \\
$\hat{y}_{2}$ & 1.82 & - & 0.02 & 0.95 \\
$\hat{\mathbf{y}}_{3}$ & 3.55 & - & - & -0.63 \\
$\hat{\mathrm{y}}_{4}$ & -1.41 & - & - & - \\
$\hat{\mathrm{y}}_{5}$ & 2.24 & - & - & -0.67 \\
$\hat{\mathrm{y}}_{6}$ & -3.14 & - & - & - \\
$\hat{\mathrm{y}}_{7}$ & 1.67 & - & - & - \\
\hline
\end{tabular}

${ }^{\#} \hat{\mathrm{y}}_{1}\left(\mathrm{~S}_{1} \mathrm{vs} \mathrm{S}_{2} ; \mathrm{S}_{3} ; \mathrm{S}_{4} ; \mathrm{S}_{5} ; \mathrm{S}_{6} ; \mathrm{S}_{7} ; \mathrm{S}_{8}\right) ; \hat{\mathrm{y}}_{2}\left(\mathrm{~S}_{2}\right.$ vs $\left.\mathrm{S}_{3}\right) ; \hat{\mathrm{y}}_{3}\left(\mathrm{~S}_{2} \mathrm{vs} \mathrm{S}_{4}\right) ; \hat{\mathrm{y}}_{4}\left(\mathrm{~S}_{3} \mathrm{vs} \mathrm{S}_{5}\right) ; \hat{\mathrm{y}}_{5}\left(\mathrm{~S}_{5} \mathrm{vs} \mathrm{S}_{6} ; \mathrm{S}_{7} ; \mathrm{S}_{8}\right) ; \hat{\mathrm{y}}_{6}\left(\mathrm{~S}_{4} \mathrm{vs} \mathrm{S}_{5}\right)$ and $\hat{\mathrm{y}}_{7}\left(\mathrm{~S}_{2} \mathrm{vs}\right.$ $\left.\mathrm{S}_{7}\right) ;(-)$ not significant.

It is also noted that plants irrigated with water prepared with sodium $\left(\mathrm{S}_{2}\right)$ had an increase of 1.82 $\mu \mathrm{mol} \mathrm{CO}_{2} \mathrm{~m}^{-2} \mathrm{~s}^{-1}$ in the $\mathrm{CO}_{2}$ assimilation rate compared to those cultivated with water prepared using calcium $\left(\mathrm{S}_{3}\right)$. When observing the contrast of $\hat{\mathrm{y}}_{3}\left(\mathrm{~S}_{2}\right.$ versus $\left.\mathrm{S}_{4}\right)$, a significant difference is verified, with an increase of $3.55 \mu \mathrm{mol} \mathrm{CO} \mathrm{CO}_{2} \mathrm{~m}^{-1}$ in the $A$ of plants subjected to salinity of water with sodic composition $\left(\mathrm{S}_{2}\right)$ compared to the treatment $\mathrm{S}_{4}$. It is also observed that when plants were irrigated with water prepared with calcium $\left(\mathrm{S}_{3}\right)$, there was a reduction of $1.41 \mathrm{~mol} \mathrm{CO} \mathrm{C}^{-2} \mathrm{~s}^{-1}$ in the $\mathrm{CO}_{2}$ assimilation rate compared to those irrigated with water salinized by sodium + calcium $\left(\mathrm{S}_{5}\right)$.

The contrast $\hat{\mathrm{y}}_{5}$ shows that plants irrigated with water composed of sodium + calcium $\left(\mathrm{S}_{5}\right)$ had an increase of $2.24 \mu \mathrm{mol} \mathrm{CO}_{2} \mathrm{~m}^{-2} \mathrm{~s}^{-1}$ in $A$ when compared with the treatments $\mathrm{S}_{6}, \mathrm{~S}_{7}$ and $\mathrm{S}_{8}$. The results obtained for the $\hat{y}_{6}$ point to a reduction of 3.14 $\mu \mathrm{mol} \mathrm{CO}_{2} \mathrm{~m}^{-2} \mathrm{~s}^{-1}$ in plants that received water salinized with magnesium $\left(\mathrm{S}_{4}\right)$ when compared to plants that received water salinized by the mixture of sodium + calcium $\left(\mathrm{S}_{5}\right)$. There was an increase of $1.67 \mu \mathrm{mol} \mathrm{CO}_{2} \mathrm{~m}^{-2} \mathrm{~s}^{-1}$ when plants received the treatment $\mathrm{S}_{2}$ compared to those receiving water related to the treatment $S_{7}$.

For stomatal conductance $(g s)$, it can be noted by the estimate of the mean (Table 2) that passion fruit plants grown under the lowest level of electrical conductivity $\left(0.4 \mathrm{dS} \mathrm{m}^{-1}\right)$ were statistically superior to those that were subjected to irrigation with water of higher salinity level $\left(3.5 \mathrm{dS} \mathrm{m}^{-1}\right)$, with an increase in $g s$ of $0.09 \mathrm{~mol} \mathrm{H}_{2} \mathrm{O} \mathrm{m}^{-2} \mathrm{~s}^{-1}$ in plants that received the treatment $\mathrm{S}_{1}$, compared to the different cationic natures of the water $\left(\mathrm{S}_{2} ; \mathrm{S}_{3} ; \mathrm{S}_{4} ; \mathrm{S}_{5} ; \mathrm{S}_{6} ; \mathrm{S}_{7}\right.$ and $\left.\mathrm{S}_{8}\right)$.

When comparing passion fruit plants subjected to the treatment $\mathrm{S}_{2}$ versus $\mathrm{S}_{4}$, an increase in gs of $0.02 \mathrm{~mol} \mathrm{H}_{2} \mathrm{O} \mathrm{m}^{-2} \mathrm{~s}^{-1}$ was noted in plants that received water salinized with sodium $\left(\mathrm{S}_{2}\right)$, compared to those that subjected to salinity of water prepared only with magnesium $\left(\mathrm{S}_{4}\right)$. There was no significant effect when comparing the treatments $S_{2}$ versus $S_{3}$, $\mathrm{S}_{3}$ versus $\mathrm{S}_{5}, \mathrm{~S}_{5}$ versus $\mathrm{S}_{6}, \mathrm{~S}_{7}$ and $\mathrm{S}_{8}, \mathrm{~S}_{4}$ versus $\mathrm{S}_{5}$ and $S_{2}$ versus $S_{7}$, indicating similar deleterious effect, regardless of the type of cation present in irrigation water (Table 2).

According to the summary of the analysis of variance for the contrasts of means related to transpiration $(E)$ (Table 2), plants grown under water salinity of $0.4 \mathrm{dS} \mathrm{m}^{-1}$ differed statistically from those subjected to the different cationic compositions of water $\left(\mathrm{S}_{2}, \mathrm{~S}_{3}, \mathrm{~S}_{4}, \mathrm{~S}_{5}, \mathrm{~S}_{6}, \mathrm{~S}_{7}\right.$ and $\left.\mathrm{S}_{8}\right)$, with an increase of $2.12 \mathrm{~mol} \mathrm{H}_{2} \mathrm{O} \mathrm{m}^{-2} \mathrm{~s}^{-1}$ in plants that received the treatment $\mathrm{S}_{1}$, in comparison to the other treatments.

When comparing plants that received irrigation water salinized with sodium $\left(\mathrm{S}_{2}\right)$ with those that received water salinized with calcium $\left(\mathrm{S}_{3}\right)$, an increase of $0.91 \mathrm{~mol} \mathrm{H}_{2} \mathrm{O} \mathrm{m}^{-2} \mathrm{~s}^{-1}$ was observed in plants irrigated with $\mathrm{S}_{2}$. Similar behavior occurred when $\mathrm{S}_{2}$ was compared with $\mathrm{S}_{4}$, where the increase in transpiration $(E)$ was equal to $0.95 \mathrm{~mol} \mathrm{H}_{2} \mathrm{O} \mathrm{m}^{-2} \mathrm{~s}^{-1}$ in plants that received $\mathrm{S}_{2}$.

When plants cultivated with water composed of calcium $\left(\mathrm{S}_{3}\right)$ were compared to those subjected to water composed of sodium + calcium $\left(\mathrm{S}_{5}\right)$, there was a reduction of $0.63 \mathrm{~mol} \mathrm{H}_{2} \mathrm{O} \mathrm{m} \mathrm{m}^{-2} \mathrm{~s}^{-1}$ in plants irrigated with calcic water $\left(\mathrm{S}_{3}\right)$. Similar result was found when comparing $S_{4}$ versus $S_{5}$, where there was a reduction of $0.67 \mathrm{~mol} \mathrm{H}_{2} \mathrm{O} \mathrm{m} \mathrm{m}^{-2}$ in plants irrigated with water salinized by magnesium $\left(\mathrm{S}_{4}\right)$ compared to the treatment $\mathrm{S}_{5}$. There was no significant effect when comparing $\mathrm{S}_{5}$ versus $\mathrm{S}_{6}, \mathrm{~S}_{7}$ 
and $\mathrm{S}_{8}$, and $\mathrm{S}_{2}$ versus $\mathrm{S}_{7}$, indicating the deleterious effect of salt stress; however, the magnitude is dependent on the type of cation present in irrigation water.

According to the analysis of variance (Table $3)$, there was a significant effect of the different cationic natures of irrigation water on the variables polar diameter, fresh fruit mass, average fruit mass and number of fruits of yellow passion fruit plants cv. BRS Rubi do Cerrado.

Table 3. Summary of the analysis of variance for equatorial diameter (ED), polar diameter (PD), fresh fruit mass (FFM), average fruit mass (AFM) and number of fruits (NFruP) of yellow passion fruit plants cv. BRS Rubi do Cerrado irrigated with water of different cationic natures, at 259 days after transplanting.

\begin{tabular}{|c|c|c|c|c|c|c|}
\hline \multirow{2}{*}{ VS/Contrasts } & \multirow{2}{*}{$\mathrm{DF}$} & \multicolumn{5}{|c|}{ Mean square } \\
\hline & & ED & PD & FFM & AFM & NFruP \\
\hline Blocks & 2 & $10.38^{\mathrm{ns}}$ & $30.17^{\mathrm{ns}}$ & $24845.50^{\mathrm{ns}}$ & $512.34^{\mathrm{ns}}$ & $3.29^{\mathrm{ns}}$ \\
\hline $\mathrm{CNW}$ & (7) & $47.11^{\mathrm{ns}}$ & $99.76^{*}$ & $155102.47^{* *}$ & $1828.80^{*}$ & $21.08^{* *}$ \\
\hline$\hat{\mathrm{y}}_{1}$ & 1 & $33.38^{\mathrm{ns}}$ & $148.53^{\mathrm{ns}}$ & $18764.66^{*}$ & $2312.66^{\mathrm{ns}}$ & $108.48^{* *}$ \\
\hline$\hat{\mathrm{y}}_{2}$ & 1 & $1.78^{\mathrm{ns}}$ & $109.73^{\text {ns }}$ & $459045.36^{* *}$ & $1823.52^{\mathrm{ns}}$ & $24.00^{*}$ \\
\hline$\hat{\mathrm{y}}_{3}$ & 1 & $14.66^{\mathrm{ns}}$ & $4.52^{\mathrm{ns}}$ & $46610.19^{\mathrm{ns}}$ & $719.85^{\mathrm{ns}}$ & $0.16^{\mathrm{ns}}$ \\
\hline$\hat{\mathrm{y}}_{4}$ & 1 & $16.93^{\mathrm{ns}}$ & $157.08^{\text {ns }}$ & $305372.16^{*}$ & $4657.63^{* *}$ & $6.00^{\mathrm{ns}}$ \\
\hline$\hat{\mathrm{y}}_{5}$ & 1 & $46.14^{\mathrm{ns}}$ & $87.45^{\mathrm{ns}}$ & $5449.63^{\mathrm{ns}}$ & $1634.85^{\mathrm{ns}}$ & $1.36^{\mathrm{ns}}$ \\
\hline$\hat{\mathrm{y}}_{6}$ & 1 & $43.68^{\mathrm{ns}}$ & $0.00^{\mathrm{ns}}$ & $8275.53^{\mathrm{ns}}$ & $2743.05^{*}$ & $4.16^{\mathrm{ns}}$ \\
\hline$\hat{\mathrm{y}}_{7}$ & 1 & $10.42^{\mathrm{ns}}$ & $60.54^{\text {ns }}$ & $186913.50^{*}$ & $1880.44^{\mathrm{ns}}$ & $8.16^{\mathrm{ns}}$ \\
\hline Residual & 14 & 19.60 & 37.32 & 37529.61 & 541.28 & 3.83 \\
\hline CV (\%) & & 7.11 & 7.67 & 39.78 & 26.05 & 34.30 \\
\hline
\end{tabular}

${ }^{\# \hat{y}_{1}}\left(\mathrm{~S}_{1} \mathrm{vs} \mathrm{S}_{2} ; \mathrm{S}_{3} ; \mathrm{S}_{4} ; \mathrm{S}_{5} ; \mathrm{S}_{6} ; \mathrm{S}_{7} \mathrm{~S}_{8}\right) ; \hat{y}_{2}\left(\mathrm{~S}_{2} \mathrm{vs} \mathrm{S}_{3}\right) ; \hat{\mathrm{y}}_{3}\left(\mathrm{~S}_{2} \mathrm{vs} \mathrm{S}_{4}\right) ; \hat{\mathrm{y}}_{4}\left(\mathrm{~S}_{3} \mathrm{vs} \mathrm{S}_{5}\right) ; \hat{y}_{5}\left(\mathrm{~S}_{5} \mathrm{vs} \mathrm{S}_{6} ; \mathrm{S}_{7} ; \mathrm{S}_{8}\right) ; \hat{\mathrm{y}}_{6}\left(\mathrm{~S}_{4} \mathrm{vs} \mathrm{S}_{5}\right)$ and $\hat{\mathrm{y}}_{7}\left(\mathrm{~S}_{2}\right.$ vs $\mathrm{S}_{7}$ ); SV - Source of variation; DF - Degree of freedom; CV - Coefficient of variation; CNW - Cationic Nature of Water; $\left({ }^{*}\right)$ Significant at 0.05 probability level; $\left({ }^{* *}\right)$ Significant at 0.01 probability level; $\left({ }^{\mathrm{ns}}\right)$ not significant.

Through the means comparison test for polar diameter (Figure 2A), it was observed that there was no significant difference between plants grown under irrigation with low-salinity water $\left(\mathrm{S}_{1}\right)$ and the treatments $\mathrm{S}_{2}, \mathrm{~S}_{4}, \mathrm{~S}_{5}$ and $\mathrm{S}_{6}$. However, when comparing the $\mathrm{PD}$ as a function of the different cationic compositions of the water, there was a significant effect only on plants irrigated with water composed of calcium $\left(\mathrm{S}_{3}\right)$, calcium + magnesium $\left(\mathrm{S}_{7}\right)$ and sodium + calcium + magnesium $\left(\mathrm{S}_{8}\right)$ compared to the treatments $\mathrm{S}_{2}, \mathrm{~S}_{4}, \mathrm{~S}_{5}$ and $\mathrm{S}_{6}$.

It is noted that, except for the treatment $\mathrm{S}_{5}$, all other treatments containing $\mathrm{Ca}^{2+}$ in their composition $\left(\mathrm{S}_{3}, \mathrm{~S}_{7}\right.$ and $\left.\mathrm{S}_{8}\right)$ had the lowest results for $\mathrm{PD}$ of yellow passion fruit cv. BRS Rubi do Cerrado. According to Pallardy (2008), among the osmotic agents, calcium chloride is the salt that has the greatest deleterious effect on plant development, as $\mathrm{Ca}^{2+}$ is a secondary messenger of signal transduction, and small variations in its concentration promote changes in the activity of enzymes linked to this nutrient.

For the fresh fruit mass per plant (Figure 2B), it was verified that there was no significant difference between plants subjected to the treatments
$\mathrm{S}_{1}$ (Control), $\mathrm{S}_{2}\left(\mathrm{Na}^{+}\right), \mathrm{S}_{5}\left(\mathrm{Na}^{+}+\mathrm{Ca}^{2+}\right)$ and $\mathrm{S}_{8}\left(\mathrm{Na}^{+}+\right.$ $\left.\mathrm{Ca}^{2+}+\mathrm{Mg}^{2+}\right)$. It is worth highlighting that the lowest values $\left(84.0 ; 460.92,416.43\right.$ and $\left.284.20 \mathrm{~g} \mathrm{plant}^{-1}\right)$ were obtained when irrigation was performed with water composed of $\mathrm{Mg}^{2+}\left(\mathrm{S}_{3}\right), \mathrm{Mg}^{2+}\left(\mathrm{S}_{4}\right) \mathrm{Na}^{+}+\mathrm{Ca}^{2+}$ $\left(\mathrm{S}_{6}\right)$ and $\mathrm{Na}^{+}+\mathrm{Mg}^{2+}\left(\mathrm{S}_{7}\right)$, respectively, with no statistical difference between the means obtained by these treatments.

For the average fruit mass (Figure 2C), it was observed that the highest values $(95.26 ; 100.73$; 121.59 and $123.31 \mathrm{~g} \mathrm{fruit}^{-1}$ ) were obtained when the plants were irrigated with water composed of $\mathrm{S}_{1}, \mathrm{~S}_{2}$, $\mathrm{S}_{5}$, and $\mathrm{S}_{8}$, respectively, statistically differing from those that received the treatments $S_{3}, S_{4}, S_{6}$ and $S_{7}$, which obtained the lowest values $(65.86$; 78.86; 63.30 and $65.49 \mathrm{~g}$ fruit $^{-1}$, respectively).

Dias et al. (2012), studying the physical quality and production of yellow passion fruit with saline waters $\left(0.5 ; 1.5 ; 2.5 ; 3.5\right.$ and $\left.4.5 \mathrm{dS} \mathrm{m} \mathrm{m}^{-1}\right)$, observed more drastic losses in fruit quality when plants were irrigated using water with $\mathrm{ECw}$ greater than $2.5 \mathrm{dS} \mathrm{m}^{-1}$, with average values of $191.29 \mathrm{~g}$ plant $^{-1}$ for plants irrigated with the lowest salinity level and $151.87 \mathrm{~g}$ fruit $^{-1}$ for plants that were irrigated using water with salinity of $3.5 \mathrm{dS} \mathrm{m}^{-1}$. 

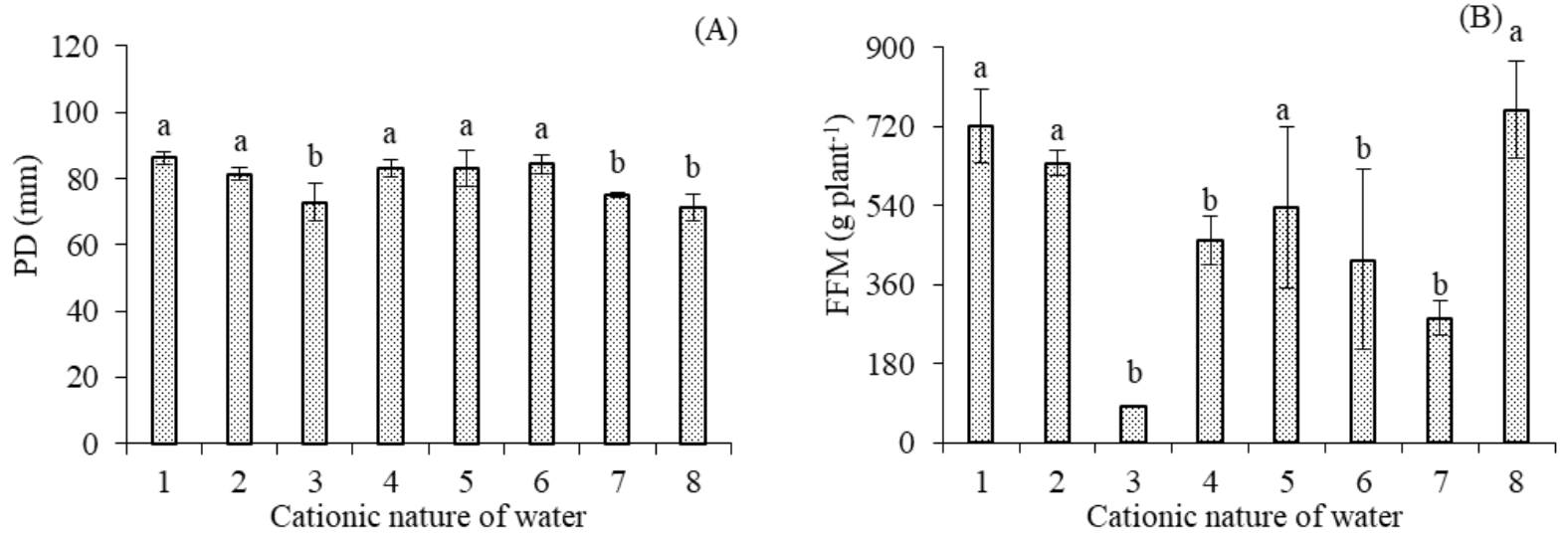

(C)
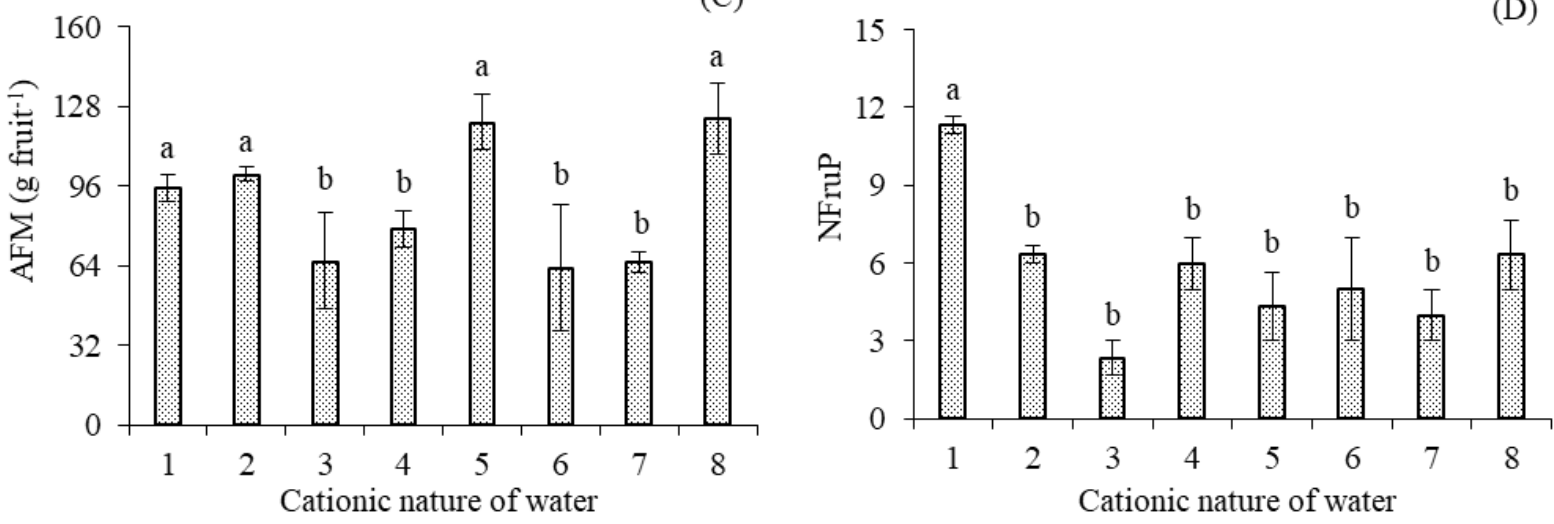

1 - Control; $2-\mathrm{Na}^{+} ; 3-\mathrm{Ca}^{2+} ; 4-\mathrm{Mg}^{2+} ; 5-\mathrm{Na}^{+}+\mathrm{Ca}^{2+} ; 6-\mathrm{Na}^{+}+\mathrm{Mg}^{2+} ; 7-\mathrm{Ca}^{2+}+\mathrm{Mg}^{2+}$ and $8-\mathrm{Na}^{+}+\mathrm{Ca}^{2+}+\mathrm{Mg}^{2+}$. Bars represent standard error of the mean $(n=3)$. Means followed by equal letters do not differ by the Scott-Knott test $(p<0.05)$.

Figure 2. Polar diameter - PD (A), fresh fruit mass - FFM (B) average fruit mass - AFM (C) and number of fruits - NFruP (D) of yellow passion fruit plants cv. BRS Rubi do Cerrado, as a function of the cationic nature of irrigation water, at 259 days after transplanting.

The number of fruits per plant was also significantly influenced by the salinity of the irrigation water and, through the means comparison test (Figure 2D), it was verified that plants irrigated with water of the control treatment $\left(\mathrm{S}_{1}\right)$ obtained higher values (11.33 fruits), differing statistically from those of all other treatments $\left(\mathrm{S}_{2}, \mathrm{~S}_{3}, \mathrm{~S}_{4}, \mathrm{~S}_{5}, \mathrm{~S}_{6}\right.$, $\mathrm{S}_{7}$ and $\mathrm{S}_{8}$ ). However, when comparing plants grown under different cationic natures, it is observed that there was no significant difference between them.

The reduction in production may be related to the action of excess salts in the soil solution, which results in the reduction of osmotic potential, imposing restriction on the absorption of water and nutrients by the plant, besides causing ionic toxicity (especially $\mathrm{Na}^{+}$and $\mathrm{Cl}^{-}$) and nutritional imbalance, negatively affecting fruit quality parameters (DIAS et al., 2012).

In addition to salt stress, another factor that may have contributed to low production or induction of flower abortion, and consequently a lower number of fruits, was thermal stress, caused by the high temperatures inside the greenhouse during the flowering and fruiting stages, being observed in this period average temperatures of $29.1^{\circ} \mathrm{C}$.

According to the summary of the analysis of variance for the contrasts of means for the fresh fruit mass (Table 4), there was a significant effect on plants irrigated with $\mathrm{ECw}$ of $0.4 \mathrm{dS} \mathrm{m} \mathrm{m}^{-1}\left(\mathrm{~S}_{1}\right)$ in comparison to those cultivated under $\mathrm{ECW}$ of $3.5 \mathrm{dS} \mathrm{m}^{-1}\left(\mathrm{~S}_{2} ; \mathrm{S}_{3} ; \mathrm{S}_{4} ; \mathrm{S}_{5} ; \mathrm{S}_{6} ; \mathrm{S}_{7}\right.$ and $\left.\mathrm{S}_{8}\right)$, where plants subjected to water of lower salinity level $\left(0.4 \mathrm{dS} \mathrm{m}^{-1}\right)$ obtained an increase in FFM of $267.37 \mathrm{~g} \mathrm{plant}^{-1}$ compared to the other treatments studied $\left(\mathrm{S}_{2}, \mathrm{~S}_{3}, \mathrm{~S}_{4}\right.$, $\mathrm{S}_{5}, \mathrm{~S}_{6}$ and $\mathrm{S}_{7}$ ). In addition, it is also observed that plants irrigated with water of sodic composition $\left(\mathrm{S}_{2}\right)$ had an increase of $553.20 \mathrm{~g} \mathrm{plant}^{-1}$ in FFM compared to those grown using water prepared with calcium $\left(\mathrm{S}_{3}\right)$.

When comparing $\mathrm{S}_{3}$ versus $\mathrm{S}_{5}$, it was observed that there was a reduction of $451.20 \mathrm{~g}$ plant ${ }^{-1}$ in plants irrigated with calcic water $\left(\mathrm{S}_{3}\right)$ in comparison to plants irrigated with water composed of sodium + calcium $\left(\mathrm{S}_{5}\right)$. When analyzing the 
contrast $\hat{y}_{7}$, corresponding to treatments $\mathrm{S}_{2}$ versus $\mathrm{S}_{7}$, there was a significant difference, with an increase in FFM of $353 \mathrm{~g} \mathrm{plant}^{-1}$ in plants that were irrigated with treatment $S_{2}$ in comparison to $S_{7}$. There was no significant effect when comparing the treatments $\mathrm{S}_{2}$ versus $\mathrm{S}_{4}, \mathrm{~S}_{5}$ versus $\mathrm{S}_{6}, \mathrm{~S}_{7}, \mathrm{~S}_{8}$ and $\mathrm{S}_{4}$ versus $\mathrm{S}_{5}$ (Table 4).

Table 4. Estimation of means for equatorial diameter (ED) and polar diameter (PD), fresh fruit mass (FFM), average fruit mass (AFM) and number of fruits (NFruP) of passion fruit plants irrigated with water of different cationic natures, at 259 days after transplanting.

\begin{tabular}{cccccc}
\hline \multirow{2}{*}{ Contrasts $^{\#}$} & \multicolumn{5}{c}{ Mean estimate } \\
\cline { 2 - 6 } & ED & PD & FFM & AFM & NFruP \\
\hline$\hat{y}_{1}$ & - & - & 267.37 & - & 6.42 \\
$\hat{y}_{2}$ & - & - & 553.20 & - & 4.00 \\
$\hat{y}_{3}$ & - & - & - & - & - \\
$\hat{y}_{4}$ & - & - & -451.20 & -55.72 & - \\
$\hat{y}_{5}$ & - & - & - & - & - \\
$\hat{y}_{6}$ & - & - & - & -42.76 & - \\
$\hat{y}_{7}$ & - & - & 353.00 & - & - \\
\hline$\hat{y}_{1}\left(\mathrm{~S}_{1}\right.$ vs $\left.\mathrm{S}_{2} ; \mathrm{S}_{3} ; \mathrm{S}_{4} ; \mathrm{S}_{5} ; \mathrm{S}_{6} ; \mathrm{S}_{7} ; \mathrm{S}_{8}\right) ; \hat{\mathrm{y}}_{2}\left(\mathrm{~S}_{2}\right.$ vs $\left.\mathrm{S}_{3}\right) ; \hat{\mathrm{y}}_{3}\left(\mathrm{~S}_{2}\right.$ vs $\left.\mathrm{S}_{4}\right) ; \hat{\mathrm{y}}_{4}\left(\mathrm{~S}_{3}\right.$ vs $\left.\mathrm{S}_{5}\right) ; \hat{\mathrm{y}}_{5}\left(\mathrm{~S}_{5}\right.$ vs $\left.\mathrm{S}_{6} ; \mathrm{S}_{7} ; \mathrm{S}_{8}\right) ; \hat{\mathrm{y}}_{6}\left(\mathrm{~S}_{4}\right.$ \\
vs $\left.\mathrm{S}_{5}\right)$ and $\hat{\mathrm{y}}_{7}\left(\mathrm{~S}_{2}\right.$ vs $\left.\mathrm{S}_{7}\right) ;(-)$ not significant.
\end{tabular}

Also according to the contrasts of means (Table 4), a significant effect was observed for the average fruit mass when comparing treatments $S_{3}$ versus $\mathrm{S}_{5}$, where it was noted that plants irrigated with water salinized by calcium $\left(\mathrm{S}_{3}\right)$ had the average fruit mass reduced by $55.72 \mathrm{~g}_{\text {fruit }^{-1}}$ compared to plants that were irrigated with water composed of sodium + calcium $\left(\mathrm{S}_{5}\right)$. On the other hand, plants irrigated with water prepared using magnesium $\left(\mathrm{S}_{4}\right)$ obtained a reduction of $42.76 \mathrm{~g}$ fruit $^{-1}$ compared to those that were subjected to salinity of the water composed of sodium + calcium $\left(\mathrm{S}_{5}\right)$.

There was no significant difference in the average fruit mass for the other contrasts of the means $\left(\hat{\mathrm{y}}_{1} ; \hat{\mathrm{y}}_{2} ; \hat{\mathrm{y}}_{3} \hat{\mathrm{y}}_{5}\right.$ and $\left.\hat{\mathrm{y}}_{7}\right)$, denoting a similar effect among the cations studied on the yellow passion fruit crop.

For the number of fruits, there was a significant effect when the treatment of low salinity $\left(\mathrm{S}_{1}\right)$ was compared to the other treatments $\left(\mathrm{S}_{2} ; \mathrm{S}_{3} ; \mathrm{S}_{4}\right.$; $\mathrm{S}_{5} ; \mathrm{S}_{6} ; \mathrm{S}_{7} ; \mathrm{S}_{8}$ ), and an increase of 6.42 fruits per plant was observed in plants that received the control treatment $\left(\mathrm{S}_{1}\right)$ in comparison to all other treatments (Table 4). A significant effect was also observed when the treatments $S_{2}$ versus $S_{3}$ were compared, where the plants subjected to salinity of the water of sodic composition $\left(\mathrm{S}_{2}\right)$ obtained an average increase of 4 fruits compared to plants that were irrigated with water salinized using calcium $\left(\mathrm{S}_{3}\right)$.

There was no significant difference for AFM when comparing the treatments $\mathrm{S}_{2}$ versus $\mathrm{S}_{4} ; \mathrm{S}_{3}$ versus $\mathrm{S}_{5} ; \mathrm{S}_{5}$ versus $\mathrm{S}_{6}, \mathrm{~S}_{7}, \mathrm{~S}_{8} ; \mathrm{S}_{4}$ versus $\mathrm{S}_{5}$ and $\mathrm{S}_{2}$ versus $S_{7}$, which indicated that the types of salts perform similar functions in the functioning of the plants.

\section{CONCLUSIONS}

Water salinity of $3.5 \mathrm{dS} \mathrm{m}^{-1}$ reduces gas exchange, and stomatal conductance and transpiration are the most sensitive variables of passion fruit.

The number of fruits of passion fruit $\mathrm{cv}$. BRS Rubi do Cerrado decreases with water salinity, regardless of the cationic nature.

Waters of calcic and calcic+magnesian nature promote the greatest deleterious effects on the production variables of passion fruit, at 259 days after transplanting.

\section{REFERENCES}

AMORIM, A. F. et al. Respostas fisiológicas de plantas adultas de cajueiro anão precoce à salinidade. Revista Ciência Agronômica, 41: 113-121, 2010.

ANDRADE, E. M. G. et al. Gas exchanges and growth of passion fruit under saline water irrigation and $\mathrm{H}_{2} \mathrm{O}_{2}$ application. Revista Brasileira de Engenharia Agrícola e Ambiental, 23: 945-951, 2019.

AYRES, R. S.; WESTCOT, D. W. A qualidade da água na agricultura. 2. ed. Campina Grande, $\mathrm{PB}$ : UFPB. 1999.153 p.

DIAS, T. J. et al. Qualidade física e produção do maracujá amarelo em solo com biofertilizante irrigado com águas salinas. Semina: Ciências 
Agrárias, 33: 2905-2918, 2012.

EMBRAPA - Empresa Brasileira de Pesquisa Agropecuária. Sistema brasileiro de classificação de solos. 5 ed. Brasília, DF: Embrapa, 2018. 353 p.

FREIRE, J. L. O.; NASCIMENTO, G. S. Produção de mudas de maracujazeiros amarelo e roxo irrigadas com águas salinas e uso de urina de vaca. Revista de Ciências Agrárias, 41: 981-988, 2018.

FREIRE, J. O. et al. Rendimento quântico e trocas gasosas em maracujazeiro amarelo sob salinidade hídrica, biofertilização e cobertura morta. Revista Ciência Agronômica, 45: 82-91, 2014.

IBGE - Instituto Brasileiro de Geografia e Estatística, Produção Agrícola Municipal 2018. Disponível em: <https://sidra.ibge.gov.br/pesquisa/ pam/tabelas $>$. Acesso em: 15 dez. 2019.

JADOSKI, S. O.; KLAR, A. E.; SALVADOR, E. D. Relações hídricas e fisiológicas em plantas de pimentão ao longo de um dia. Ambiência, 1: 11-19, 2005.

LI, Y. et al. Improving water-use efficiency by decreasing stomatal conductance and transpiration rate to maintain higher ear photosynthetic rate in drought-resistant wheat. The Crop Journal, 5: 231239, 2017.

LIMA, G. S. et al. Cell damage, water status and gas exchanges in castor bean as affected by cationic composition of water. Revista Caatinga, 32: 482$492,2019$.

LIMA, G. S. et al. Gas exchange, chloroplast pigments and growth of passion fruit cultivated with saline water and potassium fertilization. Revista Caatinga, 33:184-194, 2020a.

LIMA, L. K. S. et al. Growth, physiological, anatomical and nutritional responses of two phenotypically distinct passion fruit species (Passiflora L.) and their hybrid under saline conditions. Scientia Horticulturae, 263: 1-15, 2020b.

LIRA, R. M. et al. A utilização de águas de qualidade inferior na agricultura irrigada. Revista GEAMA, 1: 341-362, 2015.

MEDEIROS, J. F.; LISBOA, R. A.; OLIVEIRA, M. Caracterização das águas subterrâneas usadas para irrigação na área produtora de melão da Chapada do Apodi. Revista Brasileira de Engenharia Agrícola e Ambiental, 7: 469-472, 2003.
MUNNS, R.; GILLIHAM, M. Salinity tolerance of crops - what is the cost?. New Phytol, 208: 668-673, 2015.

NASCIMENTO, E. S. et al. Formação de mudas de maracujazeiro amarelo irrigadas com águas salinas e biofertilizantes de esterco bovino. Revista Agropecuária Técnica, 38: 1-8, 2017.

NOBRE, R. G. et al. Emergência, crescimento e produção da mamoneira sob estresse salino e adubação nitrogenada. Revista Ciência Agronômica, 44: 76-85, 2013.

PALLARDY, D. S. G. Molecules physiology of woody plants (Third Edition). San Diego: Academic Press, 2008. 377 p

RICHARDS, L. A. Diagnosis and improvement of saline and alkali soils. Washington: U. S Department of Agriculture, 1954. 160 p.

RODRIGUES, V. S. et al. Atributos químicos do solo em área cultivada com milho sob irrigação com água salina. Revista Brasileira de Agricultura Irrigada, 12: 3129-3138, 2018.

SANTOS, G. P. et al. Crescimento e produção do maracujazeiro amarelo sob diferentes fontes e doses de fósforo em cobertura. Bioscience Journal, 30: $525-533,2014$

SÃO JOSÉ, A. R. et al. Maracujá: Práticas de cultivo e comercialização. 1. ed. Vitória da Conquista, BA: UESB-DFZ, 2000. 79 p.

SILVA, A. A. R. et al. Gas exchanges and growth of passion fruit seedlings under salt stress and hydrogen peroxide. Pesquisa Agropecuária Tropical, 49: e55671, 2019.

SOUZA, J. T. A. et al. Effects of water salinity and organomineral fertilization on leaf composition and production in Passiflora edulis. Revista Brasileira de Engenharia Agrícola e Ambiental, 22: 535-540, 2018 .

SOUZA, R. P. et al. Fotossíntese e acúmulo de solutos em feijoeiro caupi submetido à salinidade. Pesquisa Agropecuária Brasileira, 46: 586-592, 2011.

TEIXEIRA, P. C. et al. Manual de métodos de análise de solo. 3. ed. Brasília, DF: Embrapa, 2017. $573 \mathrm{p}$. 
WANDERLEY, J. A. C. et al. Nitrogen fertilization to attenuate the damages caused by salinity on yellow passion fruit seedlings. Revista Brasileira de Engenharia Agrícola e Ambiental, 22: 541-546, 2018. 